Review Paper

\title{
Prospects of Using Wastewater as a Resource-Nutrient Recovery and Energy Generation
}

\author{
${ }^{1}$ Musfique Ahmed, ${ }^{1}$ Chowdhury Kamrul Hasan, \\ ${ }^{1}$ Hafizur Rahman, ${ }^{1}$ M. Ali Hossain and ${ }^{2}$ Sheikh Aftab Uddin \\ ${ }^{I}$ Department of Environmental Science, \\ School of Environmental Science and Management, Independent University, Bangladesh, Dhaka, Bangladesh \\ ${ }^{2}$ Institute of Marine Sciences and Fisheries, University of Chittagong, Chittagong 4331, Bangladesh
}

\author{
Article history \\ Received: 12-05-2015 \\ Revised: 02-06-2015 \\ Accepted: 23-06-2015 \\ Corresponding Author: \\ Musfique Ahmed \\ Department of Environmental \\ Science, School of Environmental \\ Science and Management, \\ Independent University, \\ Bangladesh, Dhaka, Bangladesh \\ Email: musfique1615@gmail.com
}

\begin{abstract}
It is well understood that both untreated and partially treated wastewater comprise substantial amount of resources, which can be recovered and utilized for different purposes. Since Waste Water Treatment Plant (WWTP) is energy intensive and expensive, substantiating the WWTPs with Resource Recover Technologies (RRTs) will not only save a considerable amount of energy but also make the environment cleaner and safer. In line with this, this paper seeks to review several RRTS and to identify their limitations. Several effective nutrient recovery methods using both biota (e.g., microalgae, duckweed, aquatic macrophytes) and chemical processes (e.g., struvite precipitation and HAIX resin) are discussed in this study. The recovered nutrients can be used as fertilizer, animal feed and for production of protein rich byproducts. In order to enhance the efficiency of nutrient recovery processes, several researchers suggest introducing hybrid system of nutrient recovery. On the other hand, biosolids, biogas, conserved heat, effluent flow, Microbial Fuel Cells (MFC), Microbial Electrolysis Cells (MEC) can potentially be employed to produce electricity and other forms of energy that can meet the demand of existing WWTPs. Moreover, the comparative analysis of these technologies in terms of advantages and disadvantages and their recovery potential has been discussed. The review analysis indicates that despite having limitations, several RRTs are being practiced mostly in developed world. Future research should focus on how to increase the efficiency of existing RRTs and identify innovative RRTs available in developing countries.
\end{abstract}

Keywords: Resource Recovery, Wastewater, Treatment Plant, Nutrient, Energy Generation

\section{Introduction}

Wastewater Treatment Plant (WWTP) is a prerequisite to maintain good quality of surface water as most of the treated water from wastewater plants is discharged into nearby water bodies. Inadequate treatment of wastewater allows bacteria, viruses and other disease-causing pathogens to enter groundwater and surface water. Furthermore, the whole treatment process in a WWTP requires substantial amount energy in the form of electricity, natural gas or other fuels (Stillwell et al., 2010). Additionally, waste sludge disposal is another critical factor to maintain a WWTP properly. But, waste sludge and wastewater both contain good amount of recoverable nutrient. Therefore, the wastewater industries throughout the world continue to explore sustainable resource recovery technologies considering such factors as increasing rate of population, increasing demand of sustainable resources, rigid nutrient discharge limits and strict rules for sludge disposal (Woods et al., 1999). That explains the necessity of considering wastewater as a resource (nutrient and energy). The huge amount of energy which is required to run the WWTP can be generated on-site by implementing different technologies. Efficient wastewater treatment systems possess the ability to 
produce $100 \%$ of their operational energy. These plants employ new technologies to ensure proficient operation and to recover and reuse the resources (NACWA, 2009). Similarly the nutrients conserved in wastewater can be recovered and used in fertilizer industry and other applications by provisioning nutrient recovery technologies. The overall sustainability of WWTPs can be improved by reducing the use of nonrenewable resources, minimizing waste generation and implementing resource recycling approaches. Research has been carried out on these different approaches, some of them have been done on large scale and some of them are limited to pilot scale. But, most of these technologies are applied in developed countries. This research paper works to review these technologies and to identify the limitations of these approaches. This paper is divided in to two sections- in the first section nutrient recovery approaches have been discussed while the other section deals with the energy generation technologies. A detail discussion has also been presented to comparatively analyze the knowledge gaps and limitations of these technologies.

\section{Significance of Resource Recovery from Wastewater}

Wastewater contains a high amount of organic matter, nitrogen $(\mathrm{N})$ and phosphorus $(\mathrm{P})$ (Deng et al., 2006), a considerable amount of magnesium (Mg) (Suzuki et al., 2007), different macro and micro elements (Ali and Schneider, 2008) and heavy metals (Liu et al., 2011) due to which it is considered as one of the major polluting agents discharged into the environment (Rahman et al., 2013). Most of the wastewater treatment plants are implemented with the objective of removing the nutrients from wastewater, not recycling. The main challenge of recognizing wastewater as a 'renewable' resource will begin with the recovery of these organic matters and elements. Intensive research is required to identify the full range of nutrient extracting processes and how this resource can be commoditized. In context to the present situation of the resource market and technological advancement, recovery of precious products from WWTPs is considered as a great challenge (WERF, 2010). Nitrogen and phosphorus are important organic plant nutrients and also utilized for optimization of animal and plant production. A large amount of nitrogenous and phosphate fertilizers is applied in the soil every year to increase the fertility of the soil (Rahman et al., 2013). The efficient supply of these nutrients can be ensured by implementing different nutrient recovery technologies and by extracting them from sludge and wastewater. Due to the strict discharge regulation and the depleting reserve, there is an increasing trend of research and development of wastewater treatment technologies to remove and recover these nutrients from wastes (Kelly and He, 2014; Rittmann et al., 2011). The result of removing greater concentrations of nutrients from the wastewater is that the wasted sludge has a greater concentration of phosphorus, nitrogen and magnesium (Jaffer et al., 2002). Using emerging technologies to recover nutrients from this waste sludge is the prime objective of nutrient recovery in wastewater treatment plants. Obtained nutrients can be used not only in agricultural industry but also in the production of various commodities which require nutrients as raw materials.

The energy latent in wastewater and biosolids exceeds by ten times the energy used to treat it and can potentially meet up to considerable percentage of the national electricity demand. The major concern in using fossil fuel for generating power in WWTPs is increasing of greenhouse gas emission, which has severe effect on atmosphere and also in exaggerating climate change. Wastewater utilities worldwide are involved in all areas of renewable energy, from traditional sources such as wind, solar and hydropower, to energy derived from biomass (such as biogas), to research in emerging technologies. The high amount of electricity required for generating a WWTP can be drastically reduced by on-site energy generation using these technologies. Also, Acetic acid, ammonia, aliphatic hydrocarbons, hydrogen, metals, methanol which are recoverable at the time of anaerobic digestion can be used for manufacturing emulsions, resins, plastics, synthetic fibers, adhesives, fertilizers, animal feeds, refrigerants, production of pharmaceuticals and formaldehyde etc. (WERF, 2010). Evaluation of current resource recovery options (e.g., biosolids use, nutrient recovery), as well as identifying the next generation resources (e.g., biopolymers, trace metals, chemicals, nutrients) that are cost effectively recoverable, are both highly needed in the wastewater treatment industry (WERF, 2010).

\section{Nutrient Recovery}

In this section several promising techniques of nutrient recovery from wastewater have been discussed to assess their suitability. This discussion will facilitate to identify the appropriate techniques of nutrient recovery depending on the composition of wastewater streams and nature of the treatment plant.

\section{Nutrient Recovery by Biological Organisms}

Biological organisms generally used for nutrient recovery include microalgae (Umble and Ketchum, 1997; Voltolina et al., 2005), duckweed (Alaerts et al., 1996; Cheng et al., 2002; El-Shafai et al., 2007; Oron, 
1990), wetland plants (Dixon et al., 2003; Fuchs et al., 2011; Machado et al., 2007) and crops etc. (Mo and Zhang, 2013). The recovering efficiency of these biological organisms is primly dependent on the potential biomass growth, as nutrient generally recovered through biomass production. Table 1 presents the potential uses of nutrients recovered by various biological organisms along with their biomass content.

Microalgae have good nutrient uptake, generally used for nutrient removal rather than nutrient recycling. Previous studies show the research gap on recycling techniques of nutrients by using microalgae. However, most studies provided an $\mathrm{N}$ or $\mathrm{P}$ removal rate of over $60 \%$ by aqua species (Boyden and Rababah, 1996; El-Shafai et al., 2007; Mo amd Zhang, 2012, 2013; Rectenwald and Drenner, 2000; Umble and Ketchum, 1997; Voltolina et al., 2005). Microalgae are superior among all other organisms in terms of nutrient removal as these can be grown rapidly in brackish water, so competition with other crops of arable and freshwater is avoidable (Cai et al., 2013; Chisti, 2007). Using microalgae for nutrient recovery is also cost and energy efficient compared to other conventional water treatment technologies (Mo and Zhang, 2013).

The mechanisms of algal nutrient uptake need to be understood properly to maximize the nutrient removal from different wastewater streams like domestic, industrial and agricultural. All the major nutrients i.e., carbon, phosphorus, nitrogen, sulfur need to be provided with other ionic components like sodium, potassium, iron, magnesium, calcium etc. for algal growth (Cai et al., 2013). An innovative approach is to use algal pond which is very effective in phosphorus recovery from wastewater. Relatively short retention times and shallowness contribute to the higher biomass productivity of the high rate algal ponds. The typical ponds contain $1 \%$ phosphate content of algal dry biomass, which can be increased to about $3.3 \%$ in the algal ponds (Richmond, 2003). That will also reduce costs for harvesting, transporting and spreading the biomass as a fertilizer by over $60 \%$ compared to algae with 'standard' phosphorus content (Shilton et al., 2012).

In recent years, researchers have started to work on floating macrophytes such as water hyacinth and duckweed and its role in wastewater treatment and potential for nutrient recovery (Al-Nozaily et al., 2000; Boniardi et al., 1994; Cheng et al., 2002; Ennabili et al., 1998; Skillicorn et al., 1993). In aquatic macrophytebased treatment systems, the sewage nutrients are recovered and changed into simply harvested proteinrich by-products. Recycling systems based on the treatment of municipal wastewater with protein production using duckweed represent a comprehensive solution (Culley and Epps, 1973; El-Shafai et al., 2007;
Hammouda et al., 1995; Oron et al, 1988). The duckweed has high productivity, high protein content, low fibre content, large nutrient uptake, easy handling, harvesting and processing and extensive growing period (Abdalla et al., 1987; El-Shafai et al., 2007; Hammouda et al., 1995; Oron et al., 1984; Rodrigues and Oliveira, 1987; Shelef et al., 1982). Use of duckweed pond is energy efficient process as the ammonia is converted into plant protein directly in this system (Mbagwu and Adeniji, 1988; Oron et al., 1987; Zirschky and Reed, 1988). Secondary effluent provided by the duckweed pond satisfies the irrigation and aquaculture reuse criteria and ensures annual yield of about 55 t/ha dry matter under sufficient conditions (El-Shafai et al., 2007; Oron, 1990). Upflow anaerobic sludge blanket (UASB) may play a fundamental role in the improvement of duckweed pond performance. The treatment efficiency can be improved by providing adequate pre-treatment for sewage like UASB to release nitrogen and phosphorus. The organic carbon present in effluent can affect the efficiency of duckweed ponds and pre-treatment of wastewater in a settling cone for about 8 hour may enhance the ammonia uptake (El-Shafai et al., 2007; Oron et al., 1987). A duckweed based system has been reported by $\mathrm{Xu}$ and Shen (2011) which maintains a high phosphate removal in winter despite of limited duckweed growth. This ascribed the improved protein accumulation by the duckweed and nutrient uptake by attached biofilm of algae and bacteria (Shilton et al., 2012).

Another effective approach is constructed wetland system that is generally implemented with emergent macrophytes which are adapted to grow up through the water column with their root zone and stems submerged. Constructed wetland is a biofiltration system which is often built to reduce a large amount of pollutants from waste water prior to flowing into the water body, groundwater or natural wetland (Yocum, 2006). Reed grasses, Cattails, Bulrushes are some of the most common types of plants which can be used in constructed wetland (Ahmed and Arora, 2012). Some researchers state that effective biomass growth is the preconsideration in phosphorus removal from wastewater wetlands (Korner et al., 2003). High uptake in macrophytes with phosphorus contents of up to $2.9 \%$ is achievable through this process (Chaiprapat et al., 2005). It has also been found that the contribution made by biofilms growing on the plants can be significant and has been reported to account for up to $31-71 \%$ of phosphorus removal. Recent literatures describe that the constructed wetland is more widely applied than the other technologies, but most of these constructed wetlands do not recycle the nutrients for secondary uses (Shilton et al., 2012). 
Table 1. Using of different biological organisms for nutrient recovery (Cai et al., 2013; Shilton et al., 2012)

\begin{tabular}{lll}
\hline Biological organisms & Annual Biomass yield ton/ha & Uses \\
\hline Microalgae & $69-91$ & Livestock feed \\
& & Biofuel production \\
Macrophyte (Duckweed) & $35-106$ & Fertilizer \\
& & Fish biomass \\
& Biogas production \\
Alcohol-based fuel production & Plant food \\
Macrophyte (Constructed wetland) & $35-106$ & Cattle feed \\
& & Food for aquatic organisms (fish, molluscs, shrimps) \\
& & Human food supplements \\
& & Cosmetics \\
\hline
\end{tabular}

\section{Nutrient Recovery by Chemical Process}

About $70-80 \%$ nitrogen and $50 \%$ phosphorus of domestic wastewater are contained in urine, resulting urine separation a potential method for nutrient recovery (Jönsson, 2001; Larsen and Gujer, 1996). In most of the developing countries, urine and grey water, all are collected in same connection line, so urine separation system hasn't been developed in that extent due to expensive construction requirements and aesthetic problem. But, a urine recovery rate of $70-75 \%$ has been estimated by using the urine-collecting toilets (Rossi et al., 2009). Urine treatment is complicated task due to complex composition which changes from fresh urine to hydrolyzed urine once it leaves the human body and flows through urinals, toilets and wastewater piping. Urine separation is a very energy proficient technology contrasted to other recycling technologies (Benetto et al., 2009; Flores et al., 2009; Mo and Zhang, 2013). The nutrients present in the urine can be recovered through different technologies like struvite precipitation, HAIX resins etc. Separation of urine from wastewater also decreases the pressure of excess nutrient load on WWTPs (Larsen et al., 2009).

Wastewater which contains a high amount of phosphorus and nitrogen is a good source of struvite. Although Struvite $\left(\mathrm{MgNH}_{4} \mathrm{PO}_{4} \cdot 6 \mathrm{H}_{2} \mathrm{O}\right)$ contains a significant amount of nitrogen and magnesium, it is a phosphate fertilizer and an effective alternative source of rock phosphate to maintain the agricultural production system (Rahman et al., 2013). Struvite precipitation is generally conducted by using diverse types of reactors like automated reactors (Antonini et al., 2011), simple hand-operated reactors (Etter et al., 2011) or by electrolytic magnesium dosage (Hug and Udert, 2013; O'Neal and Boyer, 2013). Struivite precipitation is preferable as the recovery process is simple and removes ammonium which is easily usable as fertilizers, thus avoiding transportation costs (Woods et al., 1999). Recovering rate of phosphate is very high by using struvite crystallization. Controlled struvite crystallization (Fig. 1) is a prominent way of nutrient recycling by taking out struvite from sludge digester liquors because of its high concentrations of phosphorus, ammonium and magnesium (Forrest et al., 2008; Martí et al., 2010). Different theoretical and experimental processes have been adopted by the researchers for the successful recovery of struvite (Abbona et al., 1982; Hao and Loosdrecht, 2006; Pastor et al., 2008; Rahman et al., 2013; Ronteltap et al., 2007; Wilsenach et al., 2007). Using of struvite precipitation has been increased worldwide due to its economic feasibility. It has been projected that a Wastewater Treatment Plant (WWTP) with a flow rate of only 20 $\mathrm{ml} / \mathrm{min}$ has the capacity to produce struvite worth of 10250 USD-25000 USD per year, which is commendable (Jaffer et al., 2002). In Japan, several full scale crystallization processes have been applied which show capacities ranging from 100 to $500 \mathrm{~kL} / \mathrm{d}$ and producing 100-500 kg/d of struvite (Mo and Zhang, 2013; Münch and Barr, 2001; Ueno and Fujii, 2001).

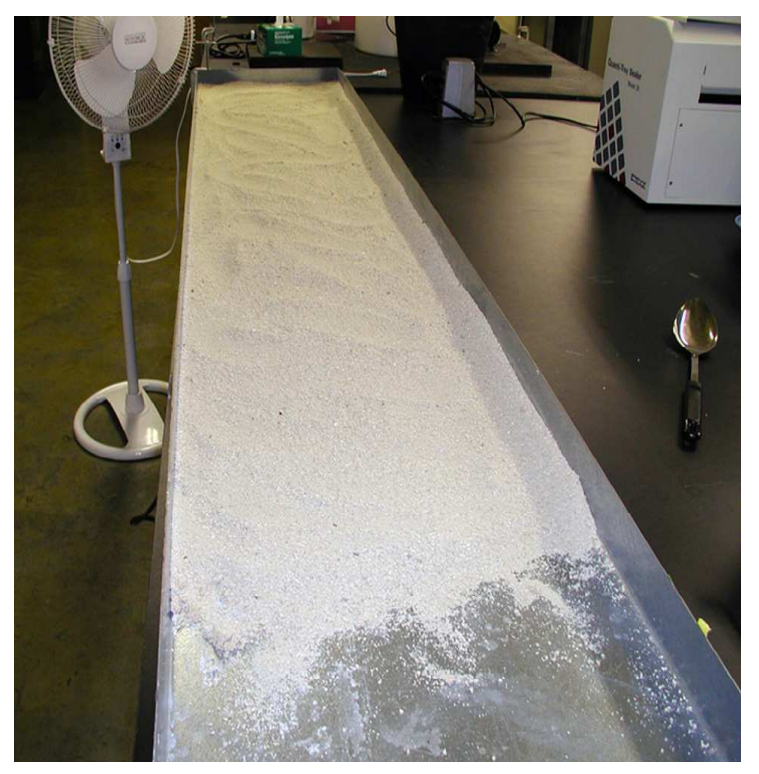

Fig. 1. Struvite crystal produced from wastewater (Rahman et al., 2013) 
Another very promising approach of nutrient recovery is using Hybrid Anion Exchange (HAIX) resin, however very little study has been done on this approach. The main component of HAIX resin is strong-base anion exchange resin which is saturated with metal oxide nanoparticles. As general strong base anion exchange resins have been developed for removal of sulfate over phosphate (Gregory and Dhond, 1972; O’Neal and Boyer, 2013), these HAIX resins have a higher selectivity for phosphate over competing anions like sulfate (Blaney et al., 2007; Pan et al., 2009; Sengupta and Pandit, 2011). Although, Hydrated Ferric Oxide (HFO) particles are physically weak and consent to only single use, they are frequently used to form the HAIX resin because of their chemical stability and cost-effectiveness. These particles bind the phosphate on the surface of HFO through the formation of inner sphere complexes (Blaney et al., 2007; Pan et al., 2009; Sendrowski and Boyer, 2013). HAIX resin is selective for phosphate in the presence of sulfate, chloride, bicarbonate and nitrate (Blaney et al., 2007; Pan et al., 2009; Sengupta and Pandit, 2011). Previous research study shows that HAIX resin can effectively remove phosphate over the $\mathrm{pH}$ range 6 to 8 and temperature has a negligible effect on phosphate removal (Blaney et al., 2007). HAIX resin has been tested for phosphate removal from lake and stream water, domestic secondary wastewater effluent, industrial wastewater effluent, reverse osmosis concentrate from wastewater treatment and sludge liquor from wastewater treatment (Blaney et al., 2007; O’Neal and Boyer, 2013; Pan et al., 2009). More than 80\% phosphate has been recovered with HAIX-FE resin (Blaney et al., 2007; Sengupta and Pandit, 2011) and by using waste regeneration solution solid-phase fertilizers can be precipitated as struvite and calcium phosphate (Kumar et al., 2007; O’Neal and Boyer, 2013).

Most of the nutrient recovery chemical processes are currently in research and development stage and few have been implemented on a full scale basis. In spite of struvite precipitation and ion exchange, calcium phosphate precipitation has also been evaluated as a promising approach. One existing process for achieving this is the DHV Crystalactor, a fludizied bed reactor. This technology has been implemented as a full scale system at the wastewater treatment plant of Geestmerambacht, Netharlands and has been operated since 1994 (Woods et al., 1999). But much study has not been found on this system.

\section{Hybrid Approaches of Nutrient Recovery}

In order to improve the sustainability of nutrient recovery system, several researches have been done by combining different systems. One of such hybrid systems is designed by coupling anaerobic fermentation and Microbial Fuel Cell (MFC) techniques with the conventional activated sludge process, thus enabling the energy recovery from sewage or sewage sludge (Ma et al., 2013; McCarty et al., 2011). Some innovative approaches have been investigated to explore the innovative treatment flow-sheets with respect to the resource recycling and reuse (Kelley et al., 2009; Sutton et al., 2011). For instance, Kelley et al. (2009) developed a hybrid system for organic carbon and struvite recovery (Ma et al., 2013). Another integrated method by combining biological process with physical-chemical unit processes has been designed by Sutton et al. (2011). The method allows the conversion of the organic matter in the wastewater to methane, the removal and recovery of phosphorus and nitrogen from the wastewater. Sutton et al. (2011) developed a new flow sheet by combining four treatment steps like an aerobic Membrane Bioreactor (MBR), a waste solids pretreatment system which is coupled with an anaerobic MBR digestion system and physicalchemical systems to achieve nutrient removal (Fig. 2). Most of the organic carbon present in the wastewater was converted into a particulate or slurry form and the solids are then digested with the anaerobic digestion system. The continuous Backwash Filter System $(\mathrm{CBF})$, operating with a reactive filter media and a comparatively little $\mathrm{Fe}$ addition rate is also a significant part of the flow sheet. The backwash releasing from this reactive filter system was then received by the underflow waste solids of the solid-liquid separation step. These underflow waste solids had the prospective to utilize as high phosphorus containing fertilizer product (Sutton et al., 2011).

In line to this hybrid concept, Ma et al. (2003) explored a new hybrid process by incorporating membrane separation reactor. This process comprises of an up flow Dynamic Membrane Separation (DMS) reactor, an anaerobic digester (or an MFC), a phosphorus recovery equipment and a Nitrogen Recovery and Water Reclamation (NRWR) system (Fig. 3) (Ma et al., 2013). In this process, organic matters of influent wastewater were harvested by using the DMS reactor with polymeric flocculant dosing. A high-strength stream was developed to concentrate the major part of the organic matters for energy recovery and the liquid effluent with ammonium flowing from the system had been utilized for fertilizer recovery. The normal operation period of the system was 300 days and on average $80 \%$ of organic matter were recovered at a membrane flux of $60 \mathrm{~L} /\left(\mathrm{m}^{2} \mathrm{~h}\right)$ in this operation period. The carbon to nitrogen mass ratio $(\mathrm{C} / \mathrm{N})$ and fermentation potential of the recovered organic matter was higher than the waste activated sludge. A relatively high ROM recovery is possible in the DMS process as it allows a sound retention of particulate fractions and biopolymers, however the dynamic membrane is less efficient to remove the little molecules (Ma et al., 2013). 


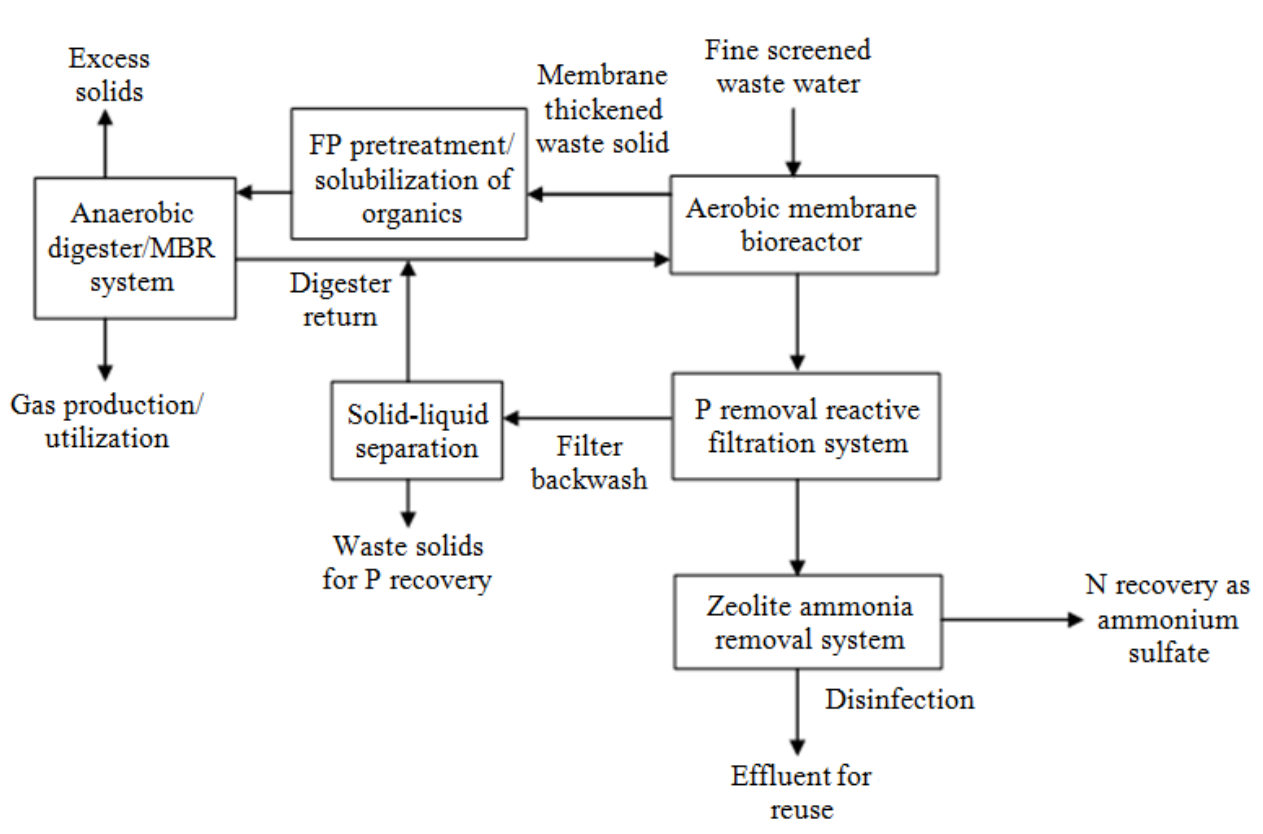

Fig. 2. Schematic representation of new flowsheet (Sutton et al., 2011)

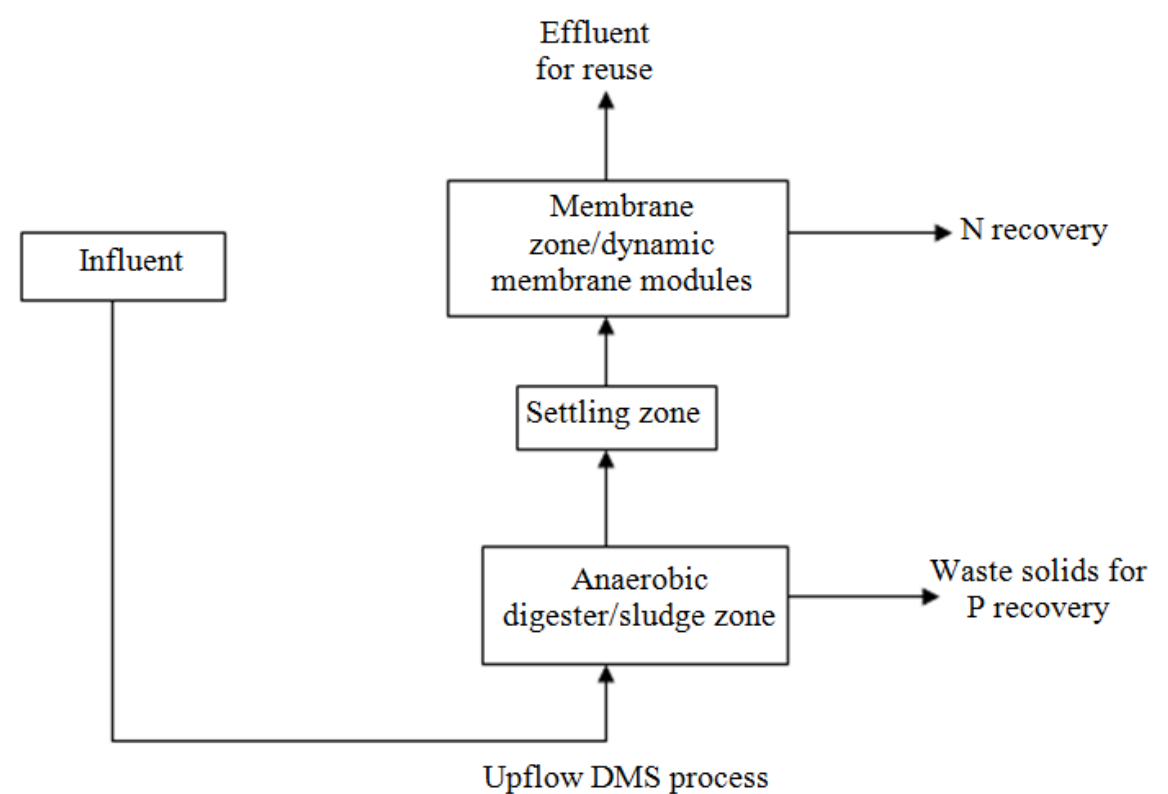

Fig. 3. The flow sheet diagram of hybrid process concept, adapted from (Ma et al., 2013)

\section{Energy Generation}

The organic matter and nutrients of wastewater, conserved thermal heat, kinetic energy produced due to wastewater flow can be used to generate on-site energy at the wastewater treatment plant. This energy production can definitely reduce the pressure on the general load of energy to run the treatment plant. Moreover, it will not only reduce the energy cost but also remove the hazardous contaminants and improve the discharged water quality. In this section several techniques and methods have been discussed which are generally applied for energy generation in WWTP worldwide.

\section{Energy Generation by Biogas}

The biogas produced from anaerobic digestion of waste can be used to heat and electricity generation. 
Combined Heat and Power system (CHP) is a significant and reliable technology to generate electricity at WWTP which has anaerobic digesters installed on them (Bennett, 2007). CHP is cost effective and environment friendly emitting less greenhouse gases and other pollutants. As it is a combination of both heat and power system, it ensures minimum use of fuel (NACWA, 2009). Around 340 Megawatts (MW) of electricity could be generated if more than 500 plants of U.S.A that presently use anaerobic digestion without CHP would have installed CHP facilities. That would also reduce emission of 2.3 million metric tons of carbon dioxide annually (NBP, 2014). An assessment of plant biogas yield and gas quality, including the degree of hydrogen sulphite and other contaminants, is required to choose the appropriate CHP engine size (Bennett, 2007). Pretreatment is effective to improve biogas production. The organic material can be transformed into biodegradable volatile solids by decomposing sludge cells in pre treatment process. Carbon dioxide $\left(\mathrm{CO}_{2}\right)$, water vapour and contaminants need to be removed to ensure improved utilization of biogas (Frijns et al., 2013). The general electrical efficiency of biogas engine is only $35 \%$, which can be increased to about $80-90 \%$ by setting up new CHP of more than $40 \%$ electric efficiency (Frijns et al., 2013) Generated electricity from biogas can be utilized to meet up the required electricity of the WWTP, so dependence on the external power system can be reduced. It has been observed that onsite energy requirement of WWTP has been met up through the generation of energy by CHP in Austria (Wett et al., 2007) and Iran (Nouri et al., 2006).

\section{Energy Generation by Biosolids}

In wastewater treatment plant, sludge is usually converted to biosolids which require huge electricity. Biosolid disposal is always a concern for municipalities which are densely populated and have a limited disposable area. Landfilling, land spreading and composting are methods of biosolid disposal whereas incineration is an alternative, more costly disposal method (Stillwell et al., 2010). But, significant energy can be generated by using biosolid incineration technology and this energy can be used for electricity generation. This is an innovative approach to managing both water and energy and suitable for medium to large wastewater treatment plant. Disposal costs can be compensated through this process as it can reduce waste volume significantly (Mo and Zhang, 2013). Multiple Hearth Furnaces (MHF) and Fluidized Bed Furnaces (FBF) are the most common equipment options available for biosolids incineration (Stillwell et al., 2010). The major components of a MHF are a refractory-lined, circular steel shell with several shelves and a central, rotating hollow cast iron shaft from where arms are expanded (Fig. 4A). Biosolids are gathered in the center of the MHF through a spiral path via the top hearth. In the middle hearth of the system, solids get burnt and ash is cooled down the bottom before discharging. Heat is released from the burnt solid and flow of hot gases are generated which also works as a countercurrent to incoming solids. Combustion efficiency can be optimized by reusing the countercurrent flow of air and solids (EPA, 2003). FBF is more efficient, more stable and easy to operate than MHF which has shell and shelves similar to MHF (Fig. 4B). A fludized sand bed works as the prime component of this system. The solids are fed in to the sand bed by using the nozzles and then the solids and heated sand get mixed. The volatile matters of the solids get burnt and the liquid is evaporated from the solids. The discharging pipe at the top of the furnace is used to discharge the ash and water vapor, whereas the whole combustion process occurs in the sand bed and freeboard (EPA, 2003).

Producing biosolids through sludge treatment often covers more than $50 \%$ of the total treatment cost. Sludge incineration process now mainly focuses on the recovery of energy for electricity production. The amount of energy that can be obtained strongly depends upon the water content of the sludge and the modification and performance of the incineration, mechanical dewatering and drying processes (Rulkens, 2008). In most new applications and retrofit incinerator designs, there is the ability of recovering heat. This is mature technology and commonly used, but still considered underutilized. Japan has done exceptionally well in practicing this technology by using about $55 \%$ of their sludge for incineration. US, Denmark, France, Belgium and Germany have used around $25,24,20,15$ and $14 \%$ of their sludge respectively for incineration (Mo and Zhang, 2013; Wang et al., 2008; Werther and Ogad, 1999).

\section{Thermal/Heat Energy Generation}

Heat pumps can be used to extract thermal energy stored in the wastewater and can produce low temperature heat from wastewater with the help of electricity. This heat can later be used for heating and cooling purposes. They are mainly applicable for onsite purposes when there are heating and cooling demands in nearby communities. This technology performs well in relatively cold climate. It has been reported that over 500 wastewater heat pumps are in operation worldwide, with thermal capacities ranging from $10 \mathrm{~kW}$ to $20 \mathrm{MW}$ (Schmid, 2008). An ideal heat pump system is consisting of compressor, condenser, evaporator and expansion valve (Fig. 5). Heat pump technology uses a reverse refrigeration cycle to factor low temperatures to useable heating levels. 


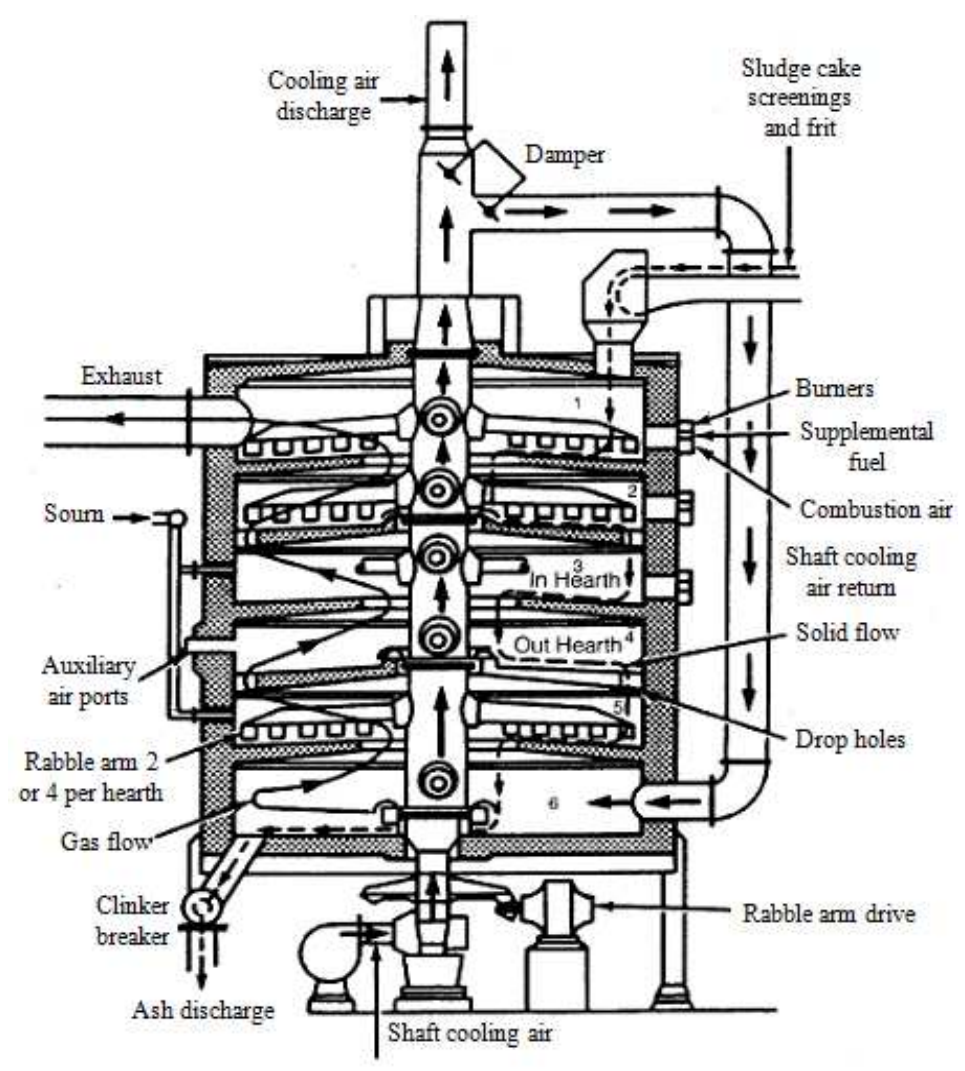

(a)

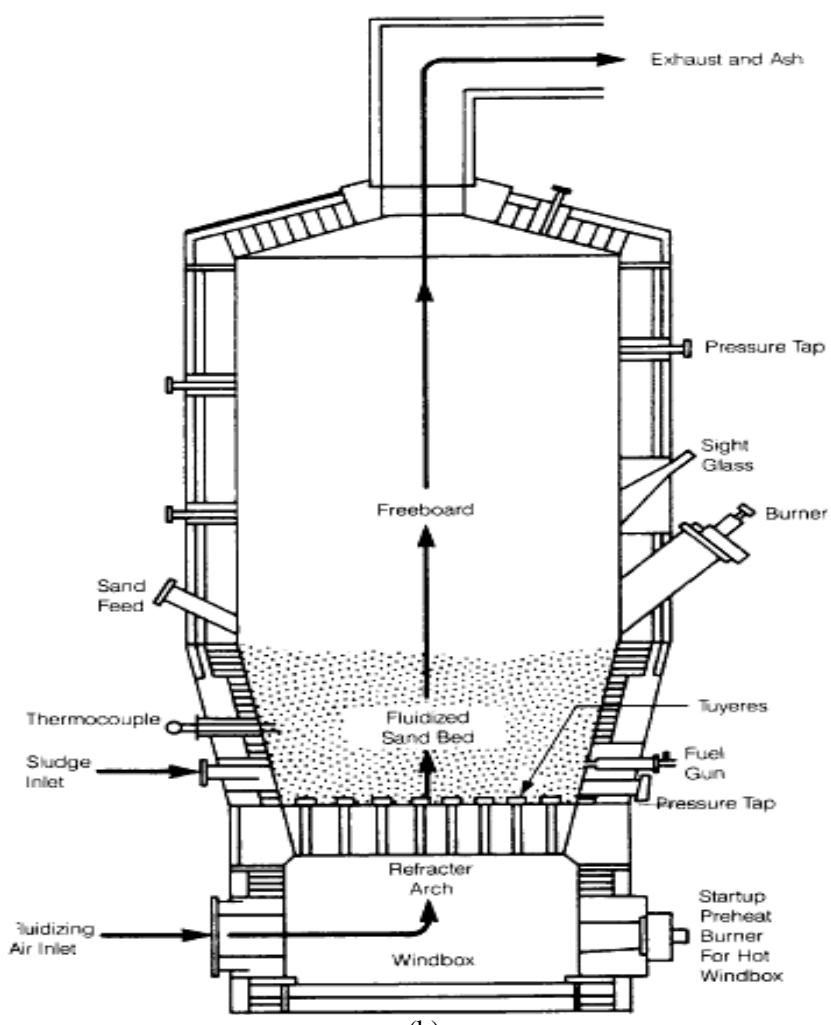

(b)

Fig. 4. (a) Multiple Hearth Furnace (b) Fludizied bed Furnace (EPA, 2003) 


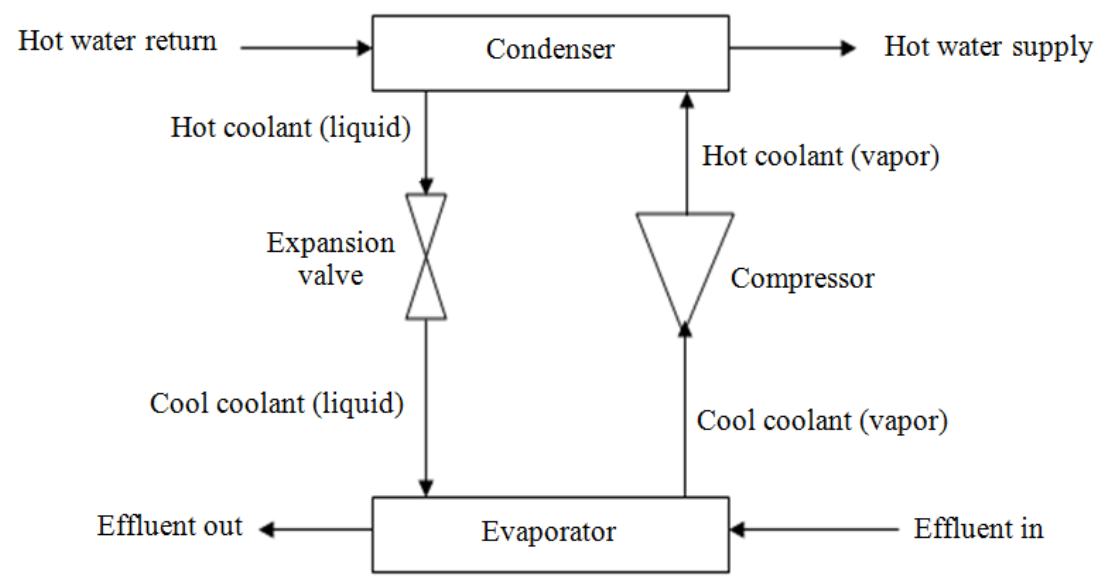

Fig. 5. Schematic diagram of heat pump, adapted from (Jacobson and Vestergaard-Hansen, 2013)

The compressor works as the primary component of the vapor-compression refrigeration cycle, which receives refrigerant as saturated vapor through evaporator. Later the refrigerant is compressed isentropically to the condenser pressure. To ensure that refrigerant is completely vaporized at the time of entering the compressor, the refrigerant is slightly superheated. Heat transformation to the circulating water makes the refrigerant a saturated liquid while leaving the condenser. The rejected heat is transferred to the storage tank via the circulation pump as heat energy.(Kahraman and Çelebi, 2009). The available heat in raw wastewater or effluent is called low grade heat. Heat recovery from raw wastewater is comparatively more challenging than from treated wastewater (effluent) as it contains solids and other constituents in concentrations much higher than those for effluent. Besides, fouling and clogging of heat exchangers are major concern in case of raw wastewater. Thus raw wastewater requires some pre-treatment prior to heat recovery process. However, a significant limitation of effluent applications is that wastewater treatment plants are not often located near the potential users of the heat. Technology currently exists to recover heat from both raw wastewater and effluent, with implemented examples found in Canada and elsewhere in the world. Although there are more complexities in the operation and maintenance of raw wastewater heat recovery systems compared to effluent applications, continued technology development will mitigate these challenges to some extent in the future (Bush and Shiskowski, 2008). Heat pumps are reliable, require low operation and maintenance costs (Neave, 2010).

\section{Hydropower Generation}

The hydraulic head loss stored as energy in the treated effluent of WWTP can also be used to generate hydroelectricity. This technology uses turbines or other devices installed in pipelines, canals and aqueducts to generate electricity from effluent water (CEC, 2005). Treated effluent of WWTP is redirected from the outfall pipeline and passed through one or more turbine generator units before discharging in to the receiving stream. Electricity that has been generated by the generator can be delivered to the wastewater plant via an independent transmission line that interconnects with the wastewater treatment plant's electrical distribution system or also can be connected to the electric utility grid (EPA, 2013). Fig. 6 illustrates a schematic diagram of a hydropower system installed in WWTP. The head difference and the water flow rate are the major considerations to ensure high energy production from hydropower plant, it requires to flow from higher level to lower level with significant speed (Gaiusobaseki, 2010). In late 70's and early 80 's, these systems have been practiced in some of WWTPs of New England but achieved partial success. About $255 \mathrm{MW}$ of electricity was produced in the man-made hydropower plant of California (CEC, 2005). Recent use of micro power turbine, which requires low head loss to generate electricity, has gained popularity. This is well developed technology and available for widespread use. Reduction in costs, improvement in technologies and notable financial incentives would be beneficial in expanding the use of micro-hydropower technologies (Curtis and Douglas, 2011).

\section{Energy Generation by Bioelectrochemical Technology}

Wastewater contains organic pollutants, hydrogen and high value chemicals which can be utilized to produce energy. Electrically-active bacteria are used in an electrochemical cell to break down the organic matter. Both biological and electrochemical processes are 
coupled to generate electricity, hydrogen and other chemicals in the Bioelectrochemical Systems (BES). Microbial Fuel Cells (MFCs) and Microbial Electrolysis Cells (MECs) are the two most renowned and developed biotechnologies. One anode-cathode combination is used in these electrochemical systems where an electrical circuit is created with the help of external wire (Fig. 7) (EC, 2013). Production of electricity is the main function of MFCs whereas MECs utilize electricity to drive chemical reactions to generate hydrogen and other chemicals. If wastewater is used in these electrochemical cells, then organic matter of the wastewater can be removed in the process. Generally bacteria are used in these cells to break down the organic material at the anode under anaerobic conditions. The bacteria release electrons, protons and carbon dioxide in the solution at the time of breaking down the organic material. The anode collects the electrons, which then travel to the cathode via an external circuit and protons travel through the solution in the cell to the cathode. The carbon dioxide then can be captured and reused to generate electricity. Thus MFCs and MECs used in wastewater treatment can not only remove organic matter from the wastewater but also can be used for nutrient recovery (EC, 2013).

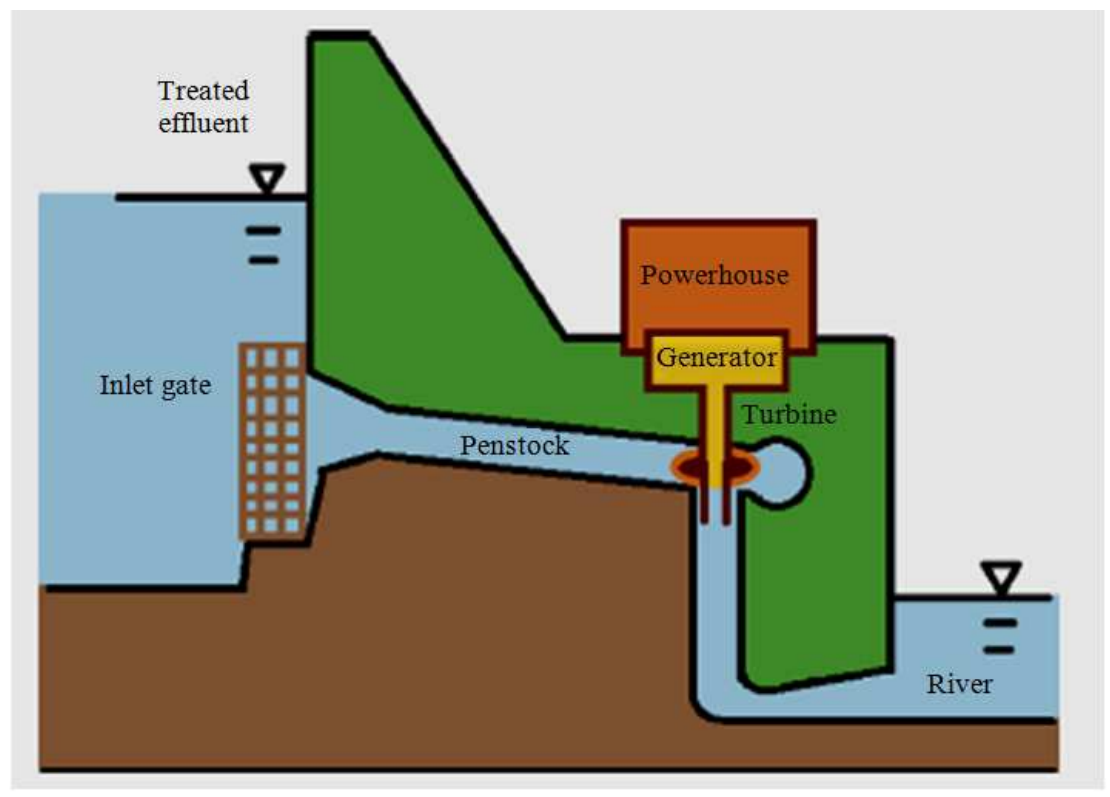

Fig. 6. Schematic diagram of hydropower generation from WWTP (Mo and Zhang, 2013)

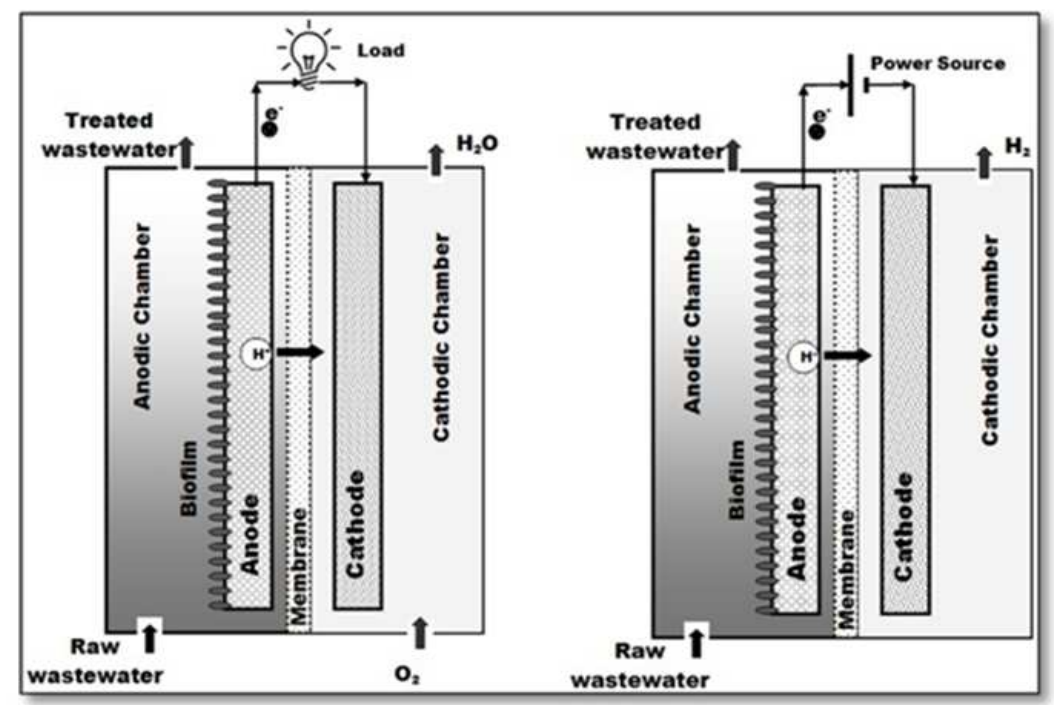

Fig. 7. Schematic diagram of MFC (left) and MEC (right) cell (Escapa et al., 2014) 
MECs are very useful as they require little energy to treat wastewater and at the same time can produce hydrogen or other chemical products. Significant energy saving is achieved as the aeration cost is reduced and the amount of sludge production is reduced (EC, 2013). MEC shows noteworthy environmental benefits than MFC in comparison with other anaerobic treatment options (Foley et al., 2010). The average power energy production is about 10 and $100 \mathrm{MW} / \mathrm{m}^{2}$ (Liu et al., 2004). Annually about 0.95 million tons of fossil fuel has been estimated to be saved in the WWTP of European Union which installed MFCs (Kim, 2009).

\section{Discussion}

Although, resource recovery has become a significant approach in terms of treating wastewater as a resource, but still there is an ample research scope in the field of application. Some of the methods are limited only to research level which has not been implemented on field. Without on-field application, the deficiencies of the methods cannot be overridden with sustainable provisions.

Most of the previous researchers focused more on the chemical treatment of recovery compared to the utilization of biological organisms. Though using organisms or aqua species can be highly beneficial but these techniques are not highly in practice. Research regarding alternative cultivation methods of algae and reuse of the biomass as a fertilizer or stock food are still in their formative years. Further research, particularly at field scale, will enhance the understanding on how to maximize the phosphorus content of the biomass and will improve the efficiency of cultivation and harvesting (Shilton et al., 2012). Constructed wetland system has been reported as the most efficient and well-known method worldwide whereas nutrient recovery through duckweeds has only been evaluated on pilot scale (El-Shafai et al., 2007). The treatment efficiency of duckweed ponds might be improved by providing adequate pre-treatment for sewage to release organically bound $\mathrm{N}$ and $\mathrm{P}$ (Alaerts et al., 1996). The efficiency can also be affected by the organic carbon presented in the wastewater as COD (Oron et al., 1987). Moreover, these RRTs are more practiced in the developed countries compared to the developing countries. Locally these systems are not well recognized and lack of expertise is found in developing countries (Nichols, 1983). Constructed wetlands have been considered for nutrient recovery in most of the previous life cycle studies (Dixon et al., 2003; Fuchs et al., 2011; Machado et al., 2007; Memon et al., 2007). Although there are lack of information in terms of end use of the aqua species as nutrients, but all the life cycle studies showed the effectiveness of constructed wetland over the conventional treatment processes. Therefore a closed nutrient loop needs be considered at the time of life cycle study on constructed wetland to assess the benefits of this system accurately. Furthermore, life cycle studies on nutrient recovery through macroalgae, microalgae, duckweed and crops require to be conducted to appraise the benefits of these systems (Mo and Zhang, 2013).

In the past decade, struvite precipitation has gained interest as a route to phosphorus recovery (Doyle and Parsons, 2002). It has been recognized as a potential raw material for fertilizer industry because of the cheaper source of nitrogen and phosphorus in wastewater and provided that the quality of crystals recovered can be controlled (Rahman et al., 2013). Scaling problem has been reported in several plants with the formation of struvite (Bhattarai et al., 1989; Jaffer et al., 2002; Mamais et al., 1994). Unintentional struvite formation can block valves, pipes, centrifuge bowls and pumps (Münch and Barr, 2001) and lead to reduced flow capacity and eventual equipment failure. The blockage of pipes leads to an increase in pumping costs; as the diameter of the pipe is reduced; more energy is required to move the sludge. Also, the time taken for the sludge to be moved from one place to another has been increased (Jaffer et al., 2002). Many investigations are carried out on struvite formation to prevent the scaling problem and explore possible exploitation for the benefit of wastewater companies and industries as a fertilizer. Except two studies, where reduction of greenhouse gas emission has been evaluated through the controlled struvite precipitation (Britton et al., 2007), economic benefit has been emphasized in most of the life cycle assessments of various struvite precipitation studies. In spite of knowing the prospective nutrient recovery from source separated urine, several gaps in knowledge are restraining the accomplishment of this stratagem. Principally, effectiveness of HAIX resin on phosphate removal from urine had not been observed in previous research works. Although by using clinoptilolite some research has assessed the effectiveness of diluted urine on ion-exchange (Kocaturk and Baykal, 2012), no specific data is found regarding their affect on phosphate removal using HAIX resin (O'Neal and Boyer, 2013). Although combination of these different systems will ensure highest amount of nutrient recovery, but hybrid methods are always neglected and minimum research works have been performed on them. Studies are required to examine the potentiality and sustainability of hybrid systems with several technologies, as each technology has its limits for the amount of nutrient it can recover. There is also no previous work that has examined which wastewater stream is most effective for nutrient recovery by using innovative hybrid systems. These knowledge gaps are needed to be addressed to ensure maximum nutrient recovery with sustainable methods. 
There are some limitations which have restricted the use of CHP, biosolid incinerator, MFC and other technologies for energy generation through wastewater treatment. High capital and operational cost is major restraint in using CHP technology. The analysis suggests that production of electricity from a CHP system requires two times the resources needed for producing electricity from the local power plant. Hence, it is not economical in terms of resource utilization to digest sludge for electricity production (Mo and Zhang, 2013). On the other hand biosolid incineration has gained popularity only on those places where waste disposal has been a foremost problem. Incineration technology also creates trouble because of uncontrolled emission of air from combustion and due to operational difficulties. Moreover, biosolids incineration can be a net energy producer only when the water content is reduced to below 30\% (McCarty et al., 2011). In case of heat pumps, extracted heat can only be used in on-site as the thermal energy cannot be transferred over long distances. Ensuring considerable head difference and significant kinetic energy confine hydropower system to be installed in all types of WWTP. MFC and MEC application is limited to pilot scale, so further investigation is required to on-field level to assess the sustainability and applicability of these technologies. Although, energy generation technologies are quite familiar and widely applied, life cycle studies on these technologies are very limited (Mo and Zhang, 2013).

\section{Conclusion}

Our literature review shows that wastewater and inadequately treated effluent contain significant amount of resources, for example, energy, nutrients and other chemicals. In view of the impact of these chemicals on the environment and the sustainability of the Wastewater Treatment Plants (WWTP), adopting Resource Recovery Technologies (RRTs), either as an integral part of WWTPs or in isolation, is highly important not only in developed countries but also in developing countries. The main objective of this paper is to portray the prospect of considering wastewater as a resource eventually which can reduce the intensity of pollution and the demand of energy and nutrient. Some of the imperative nutrient recovery and energy generation technologies have been discussed and their applications have been reviewed. Additionally their limitations have been examined. Several effective processes of nutrient recovery from wastewater using biological organisms like microalgae, duckweed, aquatic plants, chemical processes like struvite precipitation, use of HAIX resin etc. are discussed in this study. These recovered nutrients can be used as fertilizer and protein rich by-products. Moreover, several innovative hybrid approaches have been discussed which are implemented to ensure the sustainability of the nutrient recovery approaches. On-site energy generation technologies are more commonly applied and renowned compared to the nutrient recovery technologies. Biosolids, biogas, conserved heat, effluent flow, MFC, MEC can be used to generate on-site energy to produce electricity and other forms of energy for conventional onsite use. The major challenges of implementing the energy generation technologies are high construction and maintenance cost and lack of suitable area. As nutrient recovery technologies are not widely used and there are limitations in life cycle studies on these technologies, these technologies need thorough investigation and extensive application. To overcome the limitations, hybrid approaches are needed to be significantly considered as well. Moreover integration of different technologies can be encouraged by adequate funding and enhanced policy and regulations. For proper utilization of RRTs in developing countries, future research should focus on how to increase the efficiency of existing technologies and identify novel ways and means of resource recovery.

\section{Acknowledgment}

The authors of this paper acknowledge the help and support received from the Library of Independent University, Bangladesh (IUB) in collecting and purchasing the publications required to review this paper.

\section{Author's Contributions}

Musfique Ahmed: Designed and developed the concept of this paper. Reviwed most of the resource recovery technologies and coordinated the whole manuscript.

Chowdhury Kamrul Hasan: Reviwed some of the nutrient recovery technologies. $\mathrm{He}$ also wrote the manusctipt jointly whith Mr. Ahmad.

Hafizur Rahman: Did the comparison among different technologies.

M. Ali Hossain: Worked in drafting the article and provided mentorship throughout the study.

Sheikh Afatb Uddin: Critically analyzed the enrgy recovery technologies.

\section{Conflict of Interest}

No conflict of interest.

\section{References}

Abbona, F., R. Boistelle and H. Lundager, 1982. Crystallization of two magnesium phosphates, struvite and newberyite: Effect of $\mathrm{pH}$ and concentration. J. Crystal Growth, 57: 6-14. DOI: 10.1016/0022-0248(82)90242-1 
Abdalla, A.L., E.J. Ambrosano, D.M.S.S. Vitti and F.J.C. Silva, 1987. Water-hyacinth (Eichhornia crassipes) in ruminant nutrition. Water Sci. Technol., 19: 109-112.

Ahmed, M. and M. Arora, 2012. Suitability of grey water recycling as decentralized alternative water supply option for integrated urban water management. IOSR J. Eng., 2: 31-35. DOI: 10.9790/3021-02943135

Al-Nozaily, F., G. Alaerts and S. Veenstra, 2000. Performance of duckweed-covered sewage lagoonsII. Nitrogen and phosphorus balance and plant productivity. Water Res., 34: 2734-2741. DOI: $10.1016 / \mathrm{S} 0043-1354(00) 00004-\mathrm{X}$

Alaerts, G.J., R. Mahbubar and P. Kelderman, 1996. Performance analysis of a full-scale duckweedcovered sewage lagoon. Water Res., 30: 843-852. DOI: 10.1016/0043-1354(95)00234-0

Ali, M.I. and P.A. Schneider, 2008. An approach of estimating struvite growth kinetic incorporating thermodynamic and solution chemistry, kinetic and process description. Chem. Eng. Sci., 63: 3514-3525. DOI: $10.1016 /$ j.ces.2008.04.023

Antonini, S., S. Paris, T. Eichert and J. Clemens, 2011. Nitrogen and phosphorus recovery from human urine by struvite precipitation and air stripping in vietnam. CLEAN - Soil Air Water, 39: 1099-1104. DOI: $10.1002 /$ clen.201100036

Benetto, E., D. Nguyen, T. Lohmann, B. Schmitt and P. Schosseler, 2009. Life cycle assessment of ecological sanitation system for small-scale wastewater treatment. Sci. Total Environ., 407: 1506-1516. DOI: 10.1016/j.scitotenv.2008.11.016

Bennett, A., 2007. Energy efficiency: Wastewater treatment and energy production. Filtration Separat., 44: 16-19. DOI: 10.1016/S0015-1882(07)70319-1

Bhattarai, K., E. Taiganides and B. Yap, 1989. Struvite deposits in pipes and aerators. Biol. Wastes, 30: 133-147. DOI: 10.1016/0269-7483(89)90067-0

Blaney, L.M., S. Cinar and A.K. SenGupta, 2007. Hybrid anion exchanger for trace phosphate removal from water and wastewater. Water Res., 41: 1603-1613. DOI: 10.1016/j.watres.2007.01.008

Boniardi, N., G. Vatta, R. Rota, G. Nano and S. Carrà, 1994. Removal of water pollutants by Lemna gibba. Chem. Eng. J., 54: 41-48.

DOI: 10.1016/0923-0467(94)06051-7

Boyden, B.H. and A.A. Rababah, 1996. Recycling nutrients from municipal wastewater. Desalination, 106: 241-246.

DOI: $10.1016 / \mathrm{S} 0011-9164(96) 00114-2$

Britton, A., F. Sacluti, W. Oldham, A. Mohammed and D. Mavinic et al., 2007. Value from wasteestruvite recovery at the City of Edmonton's Gold Bar WWTP. Proceedings of the IWA Specialist Conference, (SC' 07), Moncton, New Brunswick, Canada.
Bush, K. and D. Shiskowski, 2008. Discussion paperheat recovery. Integrated Resource Management Strategy.

Cai, T., S.Y. Park and Y. Li, 2013. Nutrient recovery from wastewater streams by microalgae: Status and prospects. Renewable Sustainable Energy Rev., 19: 360-369. DOI: 10.1016/j.rser.2012.11.030

CEC, 2005. Integrated Energy Policy Report. California Energy Commission.

Chaiprapat, S., J.J. Cheng, J.J. Classen and S.K. Liehr, 2005. Role of internal nutrient storage in duckweed growth for swine wastewater treatment. Am. Society Agric. Eng., 48: 2247-2258.

Cheng, J., B.A. Bergmann, J.J. Classen, A.M. Stomp and J.W. Howard, 2002. Nutrient recovery from swine lagoon water by Spirodela punctata. Bioresource Technol., 81: 81-85. DOI: 10.1016/S0960-8524(01)00098-0

Chisti, Y., 2007. Biodiesel from microalgae. Biotechnol. Adv., 25: 294-306. DOI: $10.1016 /$ j.biotechadv.2007.02.001

Culley, D.D. and E.A. Epps, 1973. Use of Duckweed for Waste Treatment and Animal Feed. Water Pollut. Control Federat., 45: 337-347.

Curtis, M. and J. Douglas, 2011. Hydrokinetic energy harvester application at wastewater treatment facility outfall. Proceedings of the Chicago: Energy and Water, (CEW' 11), Chicago, Illinois, USA.

Deng, L.W., P. Zheng and Z.A. Chen, 2006. Anaerobic digestion and post-treatment of swine wastewater using IC-SBR process with bypass of raw wastewater. Process Biochem., 41: 965-969. DOI: $10.1016 /$ j.procbio.2005.10.022

Dixon, A., M. Simon and T. Burkitt, 2003. Assessing the environmental impact of two options for small-scale wastewater treatment: comparing a reedbed and an aerated biological filter using a life cycle approach. Ecol. Eng., 20: 297-308. DOI: $10.1016 / \mathrm{S} 0925-8574(03) 00007-7$

Doyle, J.D. and S.A. Parsons, 2002. Struvite formation, control and recovery. Water Res., 36: 3925-3940. DOI: 10.1016/S0043-1354(02)00126-4

El-Shafai, S.A., F.A. El-Gohary, F.A. Nasr, N.P.V.D. Steen and H.J. Gijzen, 2007. Nutrient recovery from domestic wastewater using a UASB-duckweed ponds system. Bioresource Technol., 98: 798-807. DOI: 10.1016/j.biortech.2006.03.011

Ennabili, A., M. Ater and M. Radoux, 1998. Biomass production and NPK retention in macrophytes from wetlands of the Tingitan Peninsula. Aquatic Botany, 62: 45-56. DOI: 10.1016/S0304-3770(98)00075-8

EPA, 2003. Biosolids technology fact sheet, use of incineration for biosolids management. Unites States Environmental Protection Agency. 
EPA, 2013. Renewable energy fact sheet: Low-head hydropower from wastewater. United States Environmental Protection Agency.

Escapa, A., M.I. San-Martín and A. Morán, 2014. Potential use of microbial electrolysis cells in domestic wastewater treatment plants for energy recovery. Frontier Energy Res., 2: 1-10. DOI: $10.3389 /$ fenrg.2014.00019

Etter, B., E. Tilley, R. Khadka and K.M. Udert, 2011. Low-cost struvite production using source-separated urine in Nepal. Water Res., 45: 852-862. DOI: $10.1016 /$ j.watres.2010.10.007

EC, 2013. Bioelectrochemical systems: Wastewater treatment, bioenergy and valuable chemicals delivered by bacteria. European Commission.

Flores, A., C. Buckley and R. Fenner, 2009. Selecting wastewater systems for sustainability in developing countries. Proceedings of the 11th International Conference on Urban Drainage, (CUD' 09), Edinburgh, Scotland, UK.

Foley, J.M., R.A. Rozendal, C.K. Hertle, P.A. Lant and K. Rabaey, 2010. Life cycle assessment of high-rate anaerobic treatment, microbial fuel cells and microbial electrolysis cells. Environ. Sci. Technol., 44: 3629-3637. DOI: 10.1021/es100125h

Forrest, A., K. Fattah, D. Mavinic and F. Koch, 2008. Optimizing struvite production for phosphate recovery in WWTP. J. Environ. Eng., 134: 395-402. DOI: 10.1061/(ASCE)0733-9372(2008)134:5(395)

Frijns, J., J. Hofman and M. Nederlof, 2013. The potential of (waste)water as energy carrier. Energy Conver. Manage., 65: 357-363.

DOI: 10.1016/j.enconman.2012.08.023

Fuchs, V.J., J.R. Mihelcic and J.S. Gierke, 2011. Life cycle assessment of vertical and horizontal flow constructed wetlands for wastewater treatment considering nitrogen and carbon greenhouse gas emissions. Water Res., 45: 2073-2081.

DOI: $10.1016 /$ j.watres.2010.12.021

Gaiusobaseki, T., 2010. Hydropower opportunities in the water industry. Int. J. Environ. Sci., 1: 392-402.

Gregory, J. and R.V. Dhond, 1972. Anion exchange equilibria involving phosphate, sulphate and chloride. Water Res., 6: 695-702.

DOI: 10.1016/0043-1354(72)90184-4

Hammouda, O., A. Gaber and M.S. Abdel-Hameed, 1995. Assessment of the effectiveness of treatment of wastewater-contaminated aquatic systems with Lemna gibba. Enzyme Microbial Technol., 17: 317-323. DOI: 10.1016/0141-0229(94)00013-1

Hao, X.D. and M.C.M.V. Loosdrecht, 2006. Modelbased evaluation of struvite recovery from an in-line stripper in a BNR process (BCFS). Water Sci. Technol., 53: 191-198. DOI: 10.2166/wst.2006.092
Hug, A. and K.M. Udert, 2013. Struvite precipitation from urine with electrochemical magnesium dosage. Water Res., 47: 289-299.

DOI: 10.1016/j.watres.2012.09.036

Jacobson, E. and B. Vestergaard-Hansen, 2013. Heat extraction from plant effluent: "Pumped heat pumps". Water Environment Research Foundation.

Jaffer, Y., T.A. Clark, P. Pearce and S.A. Parsons, 2002. Potential phosphorus recovery by struvite formation. Water Res., 36: 1834-1842. DOI: 10.1016/S0043-1354(01)00391-8

Jönsson, H., 2001. Source separation of human urineeseparation efficiency and effects on water emissions, crop yield, energy usage and reliability. Proceedings of the 1st International Conference on Ecological Sanitation, (CES' 01), Nining, China.

Kahraman, A. and A. Çelebi, 2009. Investigation of the performance of a heat pump using waste water as a heat source. Energies, 2: 697-713. DOI: $10.3390 /$ en20300697

Kelley, H., B. Dirk, A.l. Gibb, F. Koch and D. Mavinic, 2009. Carbon and struvite recovery from centrate at a biological nutrient removal plant. Proceedings of the Water Environment Federation, (WEF' 09), Residuals and Biosolids, pp: 409-432. DOI: $10.2175 / 193864709793846664$

Kelly, P.T. and Z. He, 2014. Nutrients removal and recovery in bioelectrochemical systems: A review. Bioresource Technol., 153: 351-360. DOI: 10.1016/j.biortech.2013.12.046

Kim, B.H., 2009. Microbial fuel cell. KISToday, 2: 4-8.

Kocaturk, N.P. and B.B. Baykal, 2012. Recovery of plant nutrients from dilute solutions of human urine and preliminary investigations on pot trials. CLEAN-Soil Air Water, 40: 538-544. DOI: $10.1002 /$ clen.201100193

Korner, S., J.E. Vermaat and S. Veenstra, 2003. The capacity of duckweed to treat wastewater: Ecological considerations for a sound design. J. Environ. Q., 32: 1583-1590. DOI: 10.2134/jeq2003.1583

Kumar, M., M. Badruzzaman, S. Adham and J. Oppenheimer, 2007. Beneficial phosphate recovery from reverse osmosis (ro) concentrate of an integrated membrane system using polymeric ligand exchanger (ple). Water Res., 41: 2211-2219. DOI: 10.1016/j.watres.2007.01.042

Larsen, T.A., A.C. Alder, R.I.L. Eggen, M. Maurer and J. Lienert, 2009. Source separation: Will we see a paradigm shift in wastewater handling? Environ. Sci. Technol., 43: 6121-6125. DOI: 10.1021/es803001r

Larsen, T.A. and W. Gujer, 1996. Separate management of anthropogenic nutrient solutions (human urine). Water Sci. Technol., 34: 87-94. DOI: 10.1016/0273-1223(96)00560-4 
Liu, H., R. Ramnarayanan and B.E. Logan, 2004. Production of electricity during wastewater treatment using a single chamber microbial fuel cell. Environ. Sci. Technol., 38: 2281-2285.

DOI: $10.1021 / \mathrm{es} 034923 \mathrm{~g}$

Liu, Y.H., J.H. Kwag, J.H. Kim and C.S. Ra, 2011. Recovery of nitrogen and phosphorus by struvite crystallization from swine wastewater. Desalination, 277: 364-369. DOI: 10.1016/j.desal.2011.04.056

Ma, J., Z. Wang, Y. Xu, Q. Wang and Z. Wu et al., 2013. Organic matter recovery from municipal wastewater by using dynamic membrane separation process. Chem. Eng. J., 219: 190-199. DOI: $10.1016 /$ j.cej.2012.12.085

Machado, A.P., L. Urbano, A.G. Brito, P. Janknecht and J.J. Salas et al., 2007. Life cycle assessment of wastewater treatment options for small and decentralized communities. Water Sci. Technol., 56: 15-22. DOI: $10.2166 /$ wst.2007.497

Mamais, D., P. Pitt, Y. Cheng, J. Loiacono and D. Jenkins, 1994. Determination of ferric chloride dose to control struvite precipitation in anaerobic sludge digesters. Water Environ. Res., 66: 912-918. DOI: 10.2175/WER.66.7.8

Martí, N., L. Pastor, A. Bouzas, J. Ferrer and A. Seco, 2010. Phosphorus recovery by struvite crystallization in WWTPs: influence of the sludge treatment line operation. Water Res., 44: 2371-2379. DOI: 10.1016/j.watres.2009.12.043

Mbagwu, I.G. and H.A. Adeniji, 1988. The nutritional content of duckweed (Lemna paucicostata hegelm.) in the Kainji Lake area, Nigeria. Aquatic Botany, 29: 357-366. DOI: 10.1016/0304-3770(88)90079-4

McCarty, P.L., J. Bae and J. Kim, 2011. Domestic wastewater treatment as a net energy producer-can this be achieved? Environ. Sci. Technol., 45: 7100-7106. DOI: 10.1021/es2014264

Memon, F., Z. Zheng, D. Butler, C. Shirley-Smith and S. Lui et al., 2007. Life cycle impact assessment of greywater recycling technologies for new developments. Environ. Monitor. Assess., 129: 27-35. DOI: 10.1007/s10661-006-9422-3

Mo, W. and Q. Zhang, 2012. Can municipal wastewater treatment systems be carbon neutral? J. Environ. Manage., 112: 360-367. DOI: $10.1016 /$ j.jenvman.2012.08.014

Mo, W. and Q. Zhang, 2013. Energy-nutrients-water nexus: Integrated resource recovery in municipal wastewater treatment plants. J. Environ. Manage., 127: 255-267. DOI: 10.1016/j.jenvman.2013.05.007

Münch, E.V. and K. Barr, 2001. Controlled struvite crystallisation for removing phosphorus from anaerobic digester sidestreams. Water Res., 35: 151-159. DOI: 10.1016/S0043-1354(00)00236-0

NBP, 2014. The Potential power of renewable energy generation from wastewater and biosolids fact sheet. Natonal Biosolids Partnership.
Neave, A., 2010. An introduction to heat pumps.

Nichols, D.S., 1983. Capacity of natural wetlands to remove nutrients from wastewater. J. Water Pollut. Control Federat., 55: 495-505.

DOI: $10.2307 / 25041910$

Nouri, J., M. Jafarinia, K. Naddafi, R. Nabizadeh and A. Mahvi et al., 2006. Energy recovery from wastewater treatment plant. Pak. J. Biol. Sci., 9: 3-6. DOI: $10.3923 /$ pjbs.2006.3.6

O'Neal, J.A. and T.H. Boyer, 2013. Phosphate recovery using hybrid anion exchange: Applications to source-separated urine and combined wastewater streams. Water Res., 47: 5003-5017. DOI: $10.1016 /$ j.watres.2013.05.037

Oron, G., 1990. Economic considerations in wastewater treatment with duckweed for effluent and nitrogen renovation. Res. J. Water Pollut. Control Federat., 62: 692-696. DOI: $10.2307 / 25043900$

Oron, G., A. De-Vegt and D. Porath, 1988. Nitrogen removal and conversion by duckweed grown on waste-water. Water Res., 22: 179-184. DOI: 10.1016/0043-1354(88)90076-0

Oron, G., D. Porath and H. Jansen, 1987. Performance of the duckweed species Lemna gibba on municipal wastewater for effluent renovation and protein production. Biotechnol. Bioeng., 29: 258-268. DOI: 10.1002/bit.260290217

Oron, G., L.R. Wildschut and D. Porath, 1984. Waste water recycling by duckweed for protein production and effluent renovation. Water Sci. Technol., 17: 803-817.

Pan, B.J., J. Wu, B.C. Pan, L. Lv and W.M. Zhang et al., 2009. Development of polymer-based nanosized Hydrated Ferric Oxides (HFOs) for enhanced phosphate removal from waste effluents. Water Res., 43: 4421-4429. DOI: 10.1016/j.watres.2009.06.055

Pastor, L., D. Mangin, R. Barat and A. Seco, 2008. A pilot-scale study of struvite precipitation in a stirred tank reactor: Conditions influencing the process. Bioresource Technol., 99: 6285-6291. DOI: $10.1016 /$ j.biortech.2007.12.003

Rahman, M.M., M.A.M. Salleh, U. Rashid, A. Ahsan and M.M. Hossain et al., 2013. Production of slow release crystal fertilizer from wastewaters through struvite crystallization-a review. Arab. J. Chem., 7: 139-155. DOI: 10.1016/j.arabjc.2013.10.007

Rectenwald, L.L. and R.W. Drenner, 2000. Nutrient removal from wastewater effluent using an ecological water treatment system. Environ. Sci. Technol., 34: 522-526. DOI: 10.1021/es9908422

Richmond, A., 2003. Handbook of Microalgal Culture: Biotechnology and Applied Phycology. 1st Edn., Wiley-Blackwell.

Rittmann, B.E., B.K. Mayer, P. Westerhoff and M. Edwards, 2011. Capturing the lost phosphorus. Chemosphere, 84: 846-853.

DOI: 10.1016/j.chemosphere.2011.02.001 
Rodrigues, A.M. and J.F.S. Oliveira, 1987. High-rate algal ponds: Treatment of wastewater and protein production: IV-chemical composition of biomass produced from swine wastes. Water Sci. Technol., 19: 243-248.

Ronteltap, M., M. Maurer and W. Gujer, 2007. Struvite precipitation thermodynamics in source-separated urine. Water Res., 41: 977-984. DOI: $10.1016 /$ j.watres.2006.11.046

Rossi, L., J. Lienert and T. Larsen, 2009. Real-life efficiency of urine source separation. J. Environ. Manage., 90: 1909-1917.

DOI: $10.1016 /$ j.jenvman.2009.01.006

Rulkens, W., 2008. Sewage sludge as a biomass resource for the production of energy: Overview and assessment of the various options. Energy Fuels, 22: 9-15. DOI: $10.1021 / \mathrm{ef} 700267 \mathrm{~m}$

Schmid, F., 2008. Sewage water: Interesting heat source for heat pumps and chillers.

Sendrowski, A. and T.H. Boyer, 2013. Phosphate removal from urine using hybrid anion exchange resin. Desalination, 322: 104-112.

DOI: $10.1016 /$ j.desal.2013.05.014

Sengupta, S. and A. Pandit, 2011. Selective removal of phosphorus from wastewater combined with its recovery as a solid-phase fertilizer. Water Res., 45: 3318-3330. DOI: 10.1016/j.watres.2011.03.044

Shelef, G., Y. Azov and R. Moraine, 1982. Nutrients removal and recovery in a two-stage high-rate algal wastewater treatment system. Water Sci. Technol., 14: 87-100.

Shilton, A.N., N. Powell and B. Guieysse, 2012. Plant based phosphorus recovery from wastewater via algae and macrophytes. Biotechnology, 23: 884-889. DOI: 10.1016/j.copbio.2012.07.002

Skillicorn, P., W. Spira and W. Journey, 1993. Duckweed Aquaculture: A New Aquatic Farming System for Developing Countries. 1st Edn., World Bank, Washington, ISBN-10: 082132067X, pp: 76.

Stillwell, A.S., D.C. Hoppock and M.E. Webber, 2010. Energy recovery from wastewater treatment plants in the United States: A case study of the energywater nexus. Sustainability, 2: 945-962. DOI: $10.3390 /$ su2040945

Sutton, P.M., H. Melcer, O.J. Schraa and A.P. Togna, 2011. Treating municipal wastewater with the goal of resource recovery. Water Sci. Technol., 63: 25-31. DOI: 10.2166/wst.2011.004

Suzuki, K., Y. Tanaka, K. Kuroda, D. Hanajima and Y. Fukumoto et al., 2007. Removal and recovery of phosphorous from swine wastewater by demonstration crystallization reactor and struvite accumulation device. Bioresource Technol., 98: 1573-1578. DOI: 10.1016/j.biortech.2006.06.008

NACWA, 2009. Renewable energy recovery opportunities from domestic wastewater. The National Association of Clean Water Agencies.
Ueno, Y. and M. Fujii, 2001. Three years experience of operating and selling recovered struvite from fullscale plant. Environ. Technol., 22: 1373-1381. DOI: $10.1080 / 09593332208618196$

Umble, A.K. and L.H. Ketchum, 1997. A strategy for coupling municipal wastewater treatment using the Sequencing Batch Reactor with effluent nutrient recovery through aquaculture. Water Sci. Technol., 35: 177-184. DOI: 10.1016/S0273-1223(96)00894-3

Voltolina, D., H. Gómez-Villa and G. Correa, 2005. Nitrogen removal and recycling by Scenedesmus obliquus in semicontinuous cultures using artificial wastewater and a simulated light and temperature cycle. Bioresource Technol., 96: 359-362.

DOI: 10.1016/j.biortech.2004.04.004

Wang, H., S.L. Brown, G.N. Magesan, A.H. Slade and M. Quintern et al., 2008. Technological options for the management of biosolids. Environ. Sci. Pollut. Res., 15: 308-317.

DOI: $10.1007 / \mathrm{s} 11356-008-0012-5$

WERF, 2010. Nutrient recovery state of the knowledge. Water Environment Research Foundation.

Werther, J. and T. Ogad, 1999. Sewage sludge combustion. Progress Energy Combust. Sci., 25: 55-116. DOI: 10.1016/S0360-1285(98)00020-3

Wett, B., K. Buchauer and C. Fimml, 2007. Energy selfsufficiency as a feasible concept for wastewater treatment systems. Proceedings of the IWA Leading Edge Technology Conference, (ETC' 07), Asian Water, Singapore.

Wilsenach, J., C. Schuurbiers and M.V. Loosdrecht, 2007. Phosphate and potassium recovery from source separated urine through struvite precipitation. Water Res., 41: 458-466. DOI: 10.1016/j.watres.2006.10.014

Woods, N.C., S.M. Sock and G.T. Daigger, 1999. Phosphorus recovery technology modeling and feasibility evaluation for municipal wastewater treatment plants. Environ. Technol., 20: 663-679. DOI: $10.1080 / 09593332008616862$

$\mathrm{Xu}, \mathrm{J}$. and G. Shen, 2011. Growing duckweed in swine wastewater for nutrient recovery and biomass production. Bioresource Technol., 102: 848-853. DOI: 10.1016/j.biortech.2010.09.003

Yocum, D., 2006. Design manual: Greywater biofiltration constructed wetland system. Bren School of Environmental Science and Management, University of California, Santa Barbara.

Zirschky, J. and S.C. Reed, 1988. The use of duckweed for wastewater treatment. Water Pollut. Control Federat., 60: 1253-1561. 